\title{
Uso da mesa densimétrica no beneficiamento de sementes de azevém
}

\author{
Rafael de Oliveira Vergara, Ádamo de Souza Araújo, Arieli Paula Nadal, Andre Pich Brunes, Ivan Ricardo \\ Carvalho, Gizele Ingrid Gadotti
}

Universidade Federal de Pelotas - UFPel. E-mail: agrorafaelvergara@gmail.com

\begin{abstract}
Resumo
O azevém é uma das principais gramíneas utilizadas nos estados do sul do Brasil para fins de produção de forragem durante os meses de inverno. Sua grande importância é apresentada devido às espécies de ocorrência natural nos campos do sul do Brasil apresentarem baixa produção de matéria seca durante o inverno. Nesse contexto, a qualidade de sementes de azevém apresenta grande importância para o correto estabelecimento de pastagens cultivadas. $O$ objetivo do presente estudo foi avaliar o benefício da utilização de mesa densimétrica no beneficiamento de lotes de sementes de azevém. Para tanto, foram utilizados dois lotes de sementes de azevém com diferentes níveis de qualidade inicial, os tratamentos foram compostos por quatro pontos de coleta na parte terminal da mesa densimétrica e o controle. Para avaliar o efeito do equipamento, foram realizados testes de germinação, emergência, condutividade elétrica, comprimento de plântulas, comprimento de raízes, peso de hectolitro e capacidade operacional. Observouse que a mesa densimétrica favorece a qualidade dos lotes de sementes, porém a qualidade inicial dos lotes é um fator decisivo na eficiência dos equipamentos.
\end{abstract}

Palavra-chave: massa especifica; Lolium multiflorum; qualidade fisiológica, sementes forrageiras.

\section{Use of the densimetric table in the benefit of ryegrass seeds}

\begin{abstract}
Ryegrass is one of the main grasses used in the southern Brazilian states for forage production during the winter months. Its great importance is presented due to the species of natural occurrence in the fields of southern Brazil presenting low dry matter production during the winter. In this context, the quality of ryegrass seeds is of great importance for the correct establishment of cultivated pastures. The objective of the present study was to evaluate the benefit of the use of densimetric table in the processing of lots of ryegrass seeds. For this, two lots of ryegrass seeds with different levels of initial quality were used, the treatments were composed by four points of collection in the terminal part of the densimetric table and the control. To evaluate the effect of the equipment, tests of germination, emergence, electrical conductivity, seedling length, root length, hectoliter weight and operational capacity were performed. It was observed that the densimetric table favors the quality of the seed lots, but the initial quality of the lots is a decisive factor in the efficiency of the equipment.
\end{abstract}

Keywords: specific mass; Lolium multiflorum; seed processing; physiological quality; forage seeds.

\section{Introduction}

Brazil presents as a large producer, exporter and consumer of forage seeds (TOMAZ et al., 2015). In the southern states of Brazil, the native field is the main source of forage in beef cattle. The use of temperate pastures, in regions with adequate climatic conditions, allows an increase in the availability of high quality fodder in the period when the tropical species paralyze its growth, providing excellent productive gains at this time of the year, when well handled. The most used forage species in these systems are black oats (Avena strigosa Schreb.) and ryegrass 
(Lolium multiflorum L.) (MARCHESAN et al., 2015).

Pastures integrated to grain crops contribute to conserving and improving soil and mitigating problems such as pests, diseases and weeds (AGUINAGA et al., 2008). In recent years, it has been observed the need to obtain an efficient seed production of high quality forage species, as a consequence of the demand to increase the pasture area cultivated in the South region of Brazil (TERRA-LOPES et al. , 2009).

In this context, the use of low-quality seeds can lead to a reduction in the speed emergence, uniformity, and total emergence, seedlings initial size and the establishment of suitable stands (HÖFS, 2004). For Kolchinski et al. (2005), these factors may still influence the accumulation of dry matter, and thus negatively affect crop yield.

Thus, the use of high-quality seed lots in establishing production fields is justified in all crops, ensuring adequate plant population over a wide range of environmental conditions during emergence (TEKRONY; EGLI, 1991). The effect of seed vigor on economic yield is also dependent on the stage at which the crop is harvested. Consequently, crops harvested during vegetative or early reproductive growth have usually shown a positive relationship between seed vigor and yield. Thus, seed vigor may affect the initial growth of the crops, and the effect tends to decrease with growth evolution (TEKRONY et al., 1991).

Therefore, for fodder species, seed quality is a prime factor for the establishment of adequate plant population, as well as for increased forage production, since this is a group of plants where the vegetative growth is the economic gain of the culture. The available research on the processing of fodder seeds is scarce, despite its importance for national and international agribusiness.

In this context, Peske et al. (2012) studying the use of the densimetric table in the seed of Brachiaria brizantha observed an improvement in the physical and physiological attributes of the seed lot, so it is advisable to include this finishing machine in the brachiaria seed processing line.

The benefit of seeds at a densimetric table is used to remove the seeds with a lower weight of one thousand seeds weight and specific mass. The research has shown for several species, that lower values of these parameters are indicative of lower physiological quality, as observed in cabbage broccoli seeds (GADOTTI et al., 2006), in forage turnip (NERY et al., 2009. For the above, the objective of the present work is to evaluate the efficiency of the densimetric table in the separation and improvement in the quality of ryegrass seed lots.

\section{Material and Methods}

Two lots of ryegrass seeds were harvested in the southern of Rio Grande do Sul during the winter months of the year 2017. These were harvested and sent to the Seed Conditioning Plant to pre-cleaning and then submitted to the densimetric table. Prior to the passage of the lots in the densimetric table, it was previously regulated and measured for inclination, volume of air and vibration, in order to provide a better separation of the material. The discharge end axis of the $1,0 \mathrm{~m}$ wide densimetric table was divided into four parts: low with $10 \mathrm{~cm}$, medium intermediate with $25 \mathrm{~cm}$, intermediate high with $25 \mathrm{~cm}$ and high with $40 \mathrm{~cm}$. The treatments consisted of the fractions obtained in the terminal feeding and in the parts: the high zone (Point 1), the intermediate intermediate zone (Point 2), the lower intermediate zone (Point 3) and the lower zone (Point 4). Seed samples were also evaluated before passage through the densimetric table, which were called feeding.

The experimental design was a randomized block, using as a source of variation the different densimetric table regions and feeding, 6 replicates were used for each treatment [(1x5) x6)], each batch was analyzed independently.

Was evaluated the Conditioning operational capacity and the quality of seeds as following. To evaluate the quality of the seeds obtained the following tests were conducted:

Operational capacity: seeds were collected for five minutes from each unloading point after the seed mass was weighed and the value converted to $\mathrm{g}^{*} \mathrm{~min}^{-1}$.

Hectoliter mass: was determined in a hectoliter scale with capacity of a quarter of a liter of seeds. The conversion calculated by mathematical formula based on Rules for Seed Analysis (BRASIL, 2009).

Germination: conducted with four subsamples of 100 seeds, seeded in gerbox plastic boxes, on three sheets of filter paper moistened with distilled and sterilized water, equivalent to 2,5 times the mass of the dry paper. The boxes were kept in germinator $\left(20^{\circ} \mathrm{C}\right)$. The counts were made at 14 days after sowing, according to the criteria established by the Rules 
for Seed Analysis (BRASIL, 2009). The results were expressed as percentage of normal seedlings.

Electrical conductivity: Four replicates of 50 pure seeds were weighed with two decimal places $(0.01 \mathrm{~g})$, placed in plastic cups $(200 \mathrm{~mL})$ with $50 \mathrm{~mL}$ of deionized water, and kept in a BOD chamber $\left(25^{\circ} \mathrm{C}\right)$ for an imbibition period of 4 hours (LOPES; FRANKE, 2010). Being the conductivity determined by the conductivity, expressed in $\mu \mathrm{S} \mathrm{cm}^{-1} \mathrm{~g}^{-1}$ of seeds.

Emergence: Four subsamples of 50 seeds were evaluated for each lot. Irrigations were carried out, when necessary, and the evaluation occurred at 15 days after sowing, when emergence of the seedlings became constant, computing the percentage of normal seedlings emerged.

Root length: five replicates were used, composed of three emerged seedlings, after which the measurement was made from the first insertion of the root to the largest end of the root, and the values were expressed in centimeters.

Seedling length: five replicates of emerged seedlings were collected, each replicate was composed of three seedlings, after which the measurement was performed from the highest end of the root to the highest end of the leaves, values were expressed in centimeters.

Data were submitted to ANOVA, and if significant Tukey test was performed with a $5 \%$ probability level.

\section{Results and Discussion}

There was a significant difference in most of the variables evaluated for seeds collected between the different points in the densimetric table, so it is allowing to infer that seed physiological quality is affected according to the table collection regions (Table 1 ).

Table 1. Seed germination $(G)$, seedling emergence $(E)$, seedling length $(S L)$, root length $(R L)$ and electrical conductivity (EC)of two ryegrass seed lots collected in different regions of densimetric table.

\begin{tabular}{|c|c|c|c|c|c|}
\hline \multicolumn{6}{|c|}{ Lot 1} \\
\hline Densimetric table position & G (\%) & $E(\%)$ & $\mathrm{SL}(\mathrm{cm})$ & $\mathrm{RL}(\mathrm{cm})$ & EC \\
\hline Control & $58 \mathrm{c}$ & $60 \mathrm{~b}$ & $11,04 \mathrm{bc}$ & $3,5 a b$ & $60,8 \mathrm{c}$ \\
\hline High & $78 \mathrm{a}$ & $81 \mathrm{a}$ & $17,68 \mathrm{a}$ & $4,6 \mathrm{a}$ & $38,5 \mathrm{~d}$ \\
\hline High intermediate & $68 \mathrm{~b}$ & $84 a$ & $13,3 \mathrm{~b}$ & $3,8 \mathrm{a}$ & $44,7 d$ \\
\hline Low Intermediate & $39 d$ & $33 c$ & $12,73 b$ & $2,23 \mathrm{bc}$ & $132,8 b$ \\
\hline Low & $14 \mathrm{e}$ & $6 d$ & $9,7 \mathrm{bc}$ & $1,7 \mathrm{c}$ & $257,2 a$ \\
\hline CV (\%) & 7,57 & 6,59 & 10,27 & 22,19 & 3,86 \\
\hline \multicolumn{6}{|c|}{ Lot 2} \\
\hline Feeding & $8 \mathrm{~b}$ & $33 \mathrm{~b}$ & $12,08 \mathrm{a}$ & $2,52 \mathrm{~b}$ & $87,8 \mathrm{c}$ \\
\hline High & $15 \mathrm{a}$ & $76 a$ & 12,42 a & $3,8 \mathrm{a}$ & 59 e \\
\hline High intermediate & $8 \mathrm{~b}$ & $30 \mathrm{bc}$ & $12,51 \mathrm{a}$ & $2,9 a b$ & $77,97 d$ \\
\hline Low Intermediate & $7 \mathrm{~b}$ & $24 \mathrm{~cd}$ & 11,76 a & $2,06 \mathrm{~b}$ & $135,45 a$ \\
\hline Low & $4 \mathrm{~b}$ & $18 \mathrm{~d}$ & 7,91 b & $1,9 \mathrm{~b}$ & $108,68 b$ \\
\hline CV (\%) & 14,1 & 8,14 & 8,76 & 19,85 & 3,75 \\
\hline
\end{tabular}

Values followed by the same letter in the column do not differ statistically by the Tukey test with a $5 \%$ level of significance.

For Lot 1 , germination was favored by the densimetric table (Table 1), with best performance observed in the high and intermediate high zone of the table, followed by feeding (unprocessed seed) low intermediate and low zones, that presented lower values than fedding zone. For Lot 2, despite the lower quality of the lot, it was noticed that the best performance of the germination was obtained in the upper zone of the densimetric table; the other regions did not differ statistically from the feeding(Table 1). The lower germination obtained in this seed lot may be due a high incidence of fungi that was observed during the germination test, but not observed during emergence test.

The Table 1, for Lot 1, it was noticed that the high and intermediate high zones presented the best performance, the lower and lower intermediate presented inferior performance than the feeding. However, it was observed that the low zone presented the worst performance for the variable. In Lot 2, it was noted that the high zone presented the highest emergency percentage, however it was observed that the 
high intermediate zone did not differ from the feeding. The low intermediate zone did not differ from the high intermediate and the low zones, which in turn presented the worst performance for vigor on this test. Demonstrating that in the same way as for germination, emergence was also influenced by the collection region. According to Marcos Filho (2009), these tests must be closely related to the emergence of the field.

It was observed that there was a great difference between the germination and emergence levels (Table 1 ), especially for Lot 2 , it where was observed best results for seedling emergence than for the germination, what could be justified by the excessive occurrence of fungi during the germination test. It is worth emphasizing that the relative humidity and temperature conditions found during the germination test are favorable to the development of fungi. However, under field sowing conditions such conditions may or may not be found.

For Lot 1 , it was observed that the seedling length (Table 1) presented the best performance in the high zone of the densimetric table, the other collection regions did not differ statistically among each other. In the seedling length for Lot 2 (Table 1), it was observed that the low zone of the densimetric table presented the worst performance. According to Marcos Filho (2005), the length of seedlings or their constituents (shoot and root) can be used as estimators of vigor. In this way it was observed that the seeds collected in the higher zones of the densimetric table, tend to present greater vigor.

For the length of root, it was observed for Lot 1 (Table 1), that the high and intermediate high zone of the table had the highest values, however they did not differ statistically from the feeding, this in turn did not differ statistically in the low intermediate zone. The lower zone of the table showed the lowest value; however it did not differ from the low intermediate. In another hand, for Lot 2, the high zone presented the highest values for this variable not statistically differing from the high intermediate zone that however did not differ from the other regions collected.

In the electrical conductivity for Lot 1 (Table 1), it was observed that the lowest values were found in the high and high intermediate of the table, the lower intermediate zone presented values higher than the feeding, the highest values were found in the low table zone. For Lot 2, the lowest values were found in the high zone, followed by the high intermediate zone; the highest values were found in the low and low intermediate zones. The principle of the electrical conductivity test is based on the deterioration process, where the increase of the deterioration occurs simultaneously to the leaching of the cellular constituents of the seeds soaked in water due to the loss of the integrity of the cell membranes systems (HEPBURN et al., 1984). Thus, the physiological quality of seeds is inversely proportional to their electrical conductivity. This fact serves as an indication of the higher level of deterioration found in the lower zones of the densimetric table.

The variable hectoliter weight (Figure 1), the Lot 1 presented the highest values in the high and intermediate high zones, in the low and low intermediate the lowest values were obtained for the hectoliter weight, showing a difference of about $70 \%$ when compare to... . For Lot 2 , a decreasing behavior was observed, where the highest value was observed in the high zone and the lowest values of hectoliter weight were obtained in the low and low intermediate zones, finding amplitude between the high and low part of the table of about $55 \%$. 
Figure 1. hectolitre weight and operational capacity of ryegrass seeds collected in four regions of the

Hectolitre weight Lot 1

$\left(\right.$ kg*het $\left.^{-1}\right)$

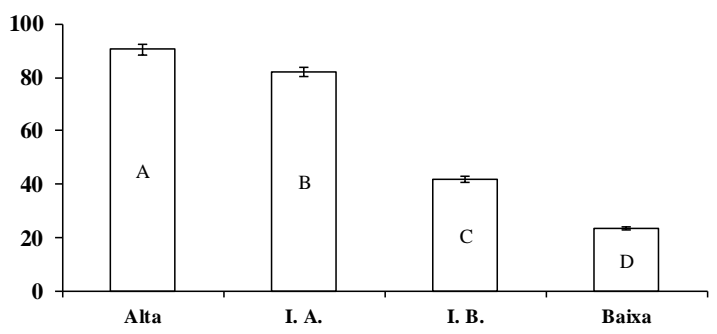

Operational capacity Lot 1 $\left(g^{*} \min ^{-1}\right)$

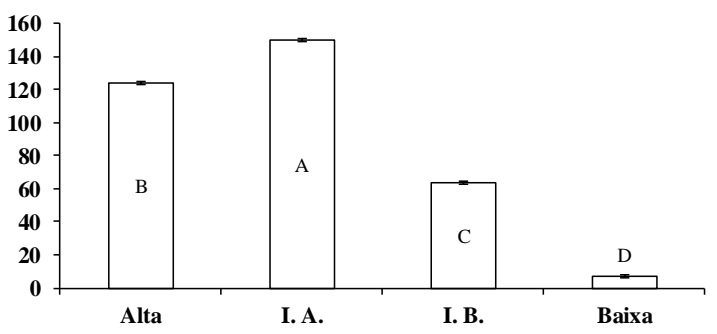

Hectolitre weight Lot 2

$\left(\right.$ kg*het $\left.^{-1}\right)$

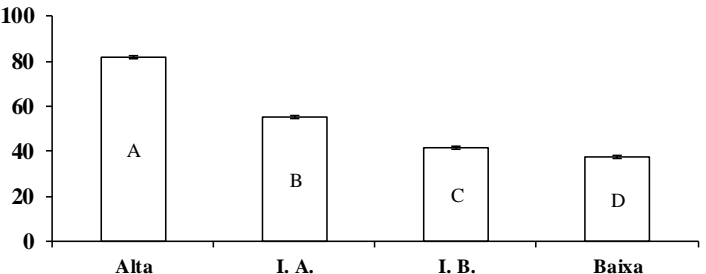

Operational capacity Lot 2 $\left(g^{*} \min ^{-1}\right)$

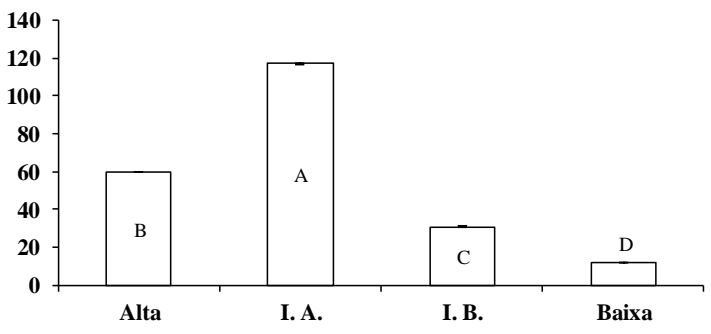

gravity table.

Figure 1 shows the operational capacity of the equipment for the different points of collection and for each lot studied. For Lot 1 , it was observed that the highest values are present in the high intermediate $(I A)$ and high zones, with the lowest values in the intermediate (IB) and low intermediate zones. For Lot 2 the same behavior was observed, however the values present a great distinction when compared to Lot 1 , this fact justified by the great difference between the mass densities of seeds found among the lots.

Observing the variables present in Table 1 it can be observed that similar behavior occurred in both lots studied. Thus, there is a trend of decreasing quality between the high and low regions. Taking into account, the principle of the electric conductivity test and the response obtained in the other variables, it is possible to infer that the seeds collected in the lower zones of the densimetric table tend to present a higher deterioration level when compared to the seeds collected in the high zone, the separation of seeds by the quality in said equipment.

It is possible to observe that the seeds coming from low and intermediate low zone should be discarded because they have the biggest statistical differences and consequently lower quality when compared to the others. Those of the high intermediate zone should be passed through with a new adjustment in the equipment for better use of the lot.
The hectoliter weight is indicative of the percentage of seeds of higher or lower specific mass within the lot. Considering the hectoliter weight in comparison to the operational capacity (Figure 1), it was obtained for Lot 1 that approximately $40 \%$ of the seeds had a hectoliter weight equal to $90(\mathrm{~kg} / \mathrm{h}$ ?)l, $30 \%$ of the seeds had a hectoliter weight of 80 while more $30 \%$ had a hectoliter weight less than 80 ?. For Lot 2, different behavior was observed in Lot 1 , where about $25 \%$ of the seeds had a hectoliter weight of about 80 , about $50 \%$ of the seeds had a hectoliter weight of about 60 and $25 \%$ of the seeds had a hectoliter weight of less than 60 .

Using a densimetric table for processing bean seeds, Mertz et al. (2009) observed that the volumetric weight of the seed lot should be related to the physiological quality of seeds. In this way seeds of higher density, tend to present better physiological quality when compared to seeds of lower density. Hessel et al. (2012) using a densimetric table for the treatment of brachiaria seeds with the objective of improving the physical and physiological quality of the lot, observed amplitude of about $40 \%$ between the ends of the table. The authors also indicate the efficiency of the equipment in the removal of seeds of lower density of the lot.

Considering, the emergence of the different discharges point collected and the minimum level of $70 \%$ of viability required for 
commercialization of ryegrass seeds, in Lot 1 it was possible to infer that there was a discard of around $20 \%$, where the high and intermediate high regions presented appropriate levels of emergency. However, the batch presented an emergency of $60 \%$ and after its passage through the densimetric table, with a loss of around $20 \%$, resulted in a lot of seeds with an emergency of over $80 \%$.

For Lot 2, it was observed that the use of the equipment did not present satisfactory results, considering the high loss for the efficiency, however the initial physiological quality of the lot was very low. In the mentioned lot, only the high zone of the densimetric table presented an adequate level of emergency, however, for selecting seeds with adequate quality, it is necessary to discard about $70 \%$ of the lot. This fact indicates that the initial quality of the seed lot is an important factor in the efficiency of said equipment, and it is not feasible to use a densimetric table in lots with low initial quality, and it is advisable to discard lots of low physiological quality before processing.

In Brazil, in general, the seeds of forage species tend to present low physical and physiological quality when compared to seeds of large crops (TOMAZ et al., 2010). The improvement of seed quality, using specific gravity separation through the use of densimetric table, occurs by the removal of lighter seeds, immature, damaged, deteriorated or containing undesirable materials, which generally have a lower specific mass than the well-formed seeds (PESKE et al., 2012).

Seeds of lower specific mass, often of lower quality, are discharged in the lower part of the discharge zone of the densimetric table, as verified by Fantinatti et al. (2002) on bean seeds, by Giomo et al. (2004) in coffee seeds, Gadotti et al. (2006b) on broccoli seeds, Ferreira and Sá (2010) on maize seeds, Gadotti et al. (2011) in tobacco seeds and Melo et al. (2016) in Tanzania grass seeds (Panicum maximum).

The results obtained in the present work corroborate with the above mentioned authors, where the data obtained describe the separation based on the specific mass, as well as the relationship between this and the variables: germination, emergence, electrical conductivity and seedling length. Thus, it was observed that seeds collected in the higher zones of the table tend to present higher levels of physiological quality.
Studying the effect of the steps of the seed conditioning, Ferreira and Sá (2010) concluded that improves the quality of the corn seeds. The authors observed that the seeds obtained after the passage through the densimetric table presented higher quality than those previously collected. In a similar work with soybean seeds, Neves et al. (2016) concluded that all the stages provide an increase in the attributes of lot quality, however, the densimetric table plays an important role in the lot vigor level.

It is worth emphasizing that, it was observed that the initial quality of the lot is a decisive factor in the final quality of the lot after the passage through the densimetric table. In the present work, it was observed that Lot 2 presented atypical behavior during the passage through the densimetric table, being related to its greater deterioration, which culminated in a lower specific mass when compared to the batch of higher quality. In view of the equipment principle, which requires materials with significant density difference within the same seed mass (lot), the use of low specific gravity seeds tends to impair the performance of the equipment in terms of operating efficiency. Most of the producing companies have difficulties in regulating the equipment for each lot to be conditioning, so it is recommended that seed of adequate initial quality level be used so that success can be achieved at the end of the beneficiation process, since a maximum of $30 \%$.

For the above, it is advisable to use a densimetric table on the ryegrass seed conditioning plant. However, for lots with low initial quality, the performance of the equipment tends not to be satisfactory. It is important to emphasize that, in order to obtain the maximum benefit of the equipment, it is of great importance that the equipment is regulated for each batch to be conditioning.

\section{Conclusions}

The densimetric table presents efficiency in the separation of ryegrass seeds at different levels of quality according to the fraction of the discharge.

The use of densimetric table provides improvement in lot quality of ryegrass seeds.

The initial quality of the lots of ryegrass seeds directly influences the efficiency of the equipment. 


\section{References}

AGUINAGA, A.A.Q.; CARVALHO, P.C.F.; ANGHINONI, I.; PILAU, A.; AGUINAGA, A.J.Q.; GIANLUPPI, G.D.F. Componentes morfológicos e produção de forragem de pastagem de aveia e azevém manejada em diferentes alturas. Revista Brasileira de Zootecnia, v. 37, p.1523-1530, 2008. https://doi.org/10.1590/S1516-

\section{2}

BRASIL. Ministério da Agricultura, Pecuária e Abastecimento. Regras para análise de sementes. Brasilia, 2009.

FANTINATTI, J.B.; HONÓRIO, S.L.; RAZERA, L.F. Qualidade de sementes de feijão de diversas densidades obtidas na mesa gravitacional. Revista Brasileira de Sementes, v.24, p.24-32, $2002 . \quad$ https://doi.org/10.1590/S0101$\underline{31222002000100005}$

FERREIRA, R.L.; SÁ, M.E. Qualidade fisiológica de sementes durante o beneficiamento. Revista Brasileira de Sementes, v.32, p.99-110, 2010. https://doi.org/10.1590/S0101$\underline{31222010000400011}$

GADOTTI, G.I.; CORRÊA, C.L.; LUCCA FILHO, O.A.; VILLELA, F.A. Qualidade de sementes de couve brócolis beneficiadas em mesa densimétrica. Revista Brasileira de Sementes, v.28, p.123-127, $2006 . \quad$ https://doi.org/10.1590/S0101$\underline{31222006000200016}$

GADOTTI, G.I.; VILLELA, F.A.; BAUDET, L. Influência da mesa densimétrica na qualidade de sementes de cultivares de tabaco. Revista Brasileira de Sementes, v.33, p.372-378, 2011. https://doi.org/10.1590/S0101-

31222011000200020

GIOMO, G.S.; RAZERA, L.F.; GALLO, P.B. Beneficiamento e qualidade de sementes de café arábica. Bragantia, v.63, p.291-297, 2004. https://doi.org/10.1590/S0006-

\section{$\underline{87052004000200014}$}

HEPBURN, H.A.; POWELL, A.A.; MATTHEWS, S. Problems associated with the routine application of electrical conductivity measurements of individual seeds in the germination testing of peas and soybeans. Seed Science and Technology, v.12, p.403-413, 1984.
HESSEL, C.L.E.; VILLELA, F.A.; AUMONDE, T.Z.; PEDO, T. Mesa densimétrica e qualidade fisiológica de sementes de brachiária. Informativo Abrates, v.22, p.73-76, 2012.

HÖFS, A.; SCHUCH, L.O.B.; PESKE, S.T.; BARROS, A.C.S.A. Emergência e crescimento de plântulas de arroz em resposta à qualidade fisiológica de sementes. Revista Brasileira de Sementes, v.26, p.92-97, 2004. https://doi.org/10.1590/S0101$\underline{31222004000100014}$

KOLCHINSKI, E.M.; SCHUCH, L.O.B.; PESKE, S.T. Vigor de sementes e competição intra-específica em soja. Ciência Rural, v.35, p.1248-1256, 2005. https://doi.org/10.1590/S010384782005000600004

LOPES, R.R.; FRANKE, L.B. Teste de condutividade elétrica para avaliação da qualidade fisiológica de sementes de azevém (Lolium multiflorum L.). Revista Brasileira de Sementes, v.32, p.123-130, $2010 . \quad$ https://doi.org/10.1590/S0101$\underline{31222010000100014}$

MARCHESAN, R.; PARIS, W.; TONION, R.; MARTINELLO, C.; MOLINETE, M.L.; PAULA, F.; ROCHA, R. Valor nutricional de cultivares de azevém consorciados ou não com aveia sob dois resíduos de pastejo. Revista de Ciências Agroveterinárias, v.14, p.254-263, 2015. https://doi.org/10.5965/223811711432015254

MARCOS FILHO, J. Fisiologia de sementes de plantas cultivadas. Piracicaba. 2005.

MARCOS FILHO, J.; KIKUTI, A.L.P.; LIMA, L.B. Métodos para avaliação do vigor de sementes de soja, incluindo a análise computadorizada de imagens. Revista Brasileira de Sementes, v.31, p.102-112, 2009. https://doi.org/10.1590/S0101$\underline{31222009000100012}$

MELO, L.F.; MARTINS, C.C.; SILVA, G.Z.; SANCHES, M.F.G. Processing in the quality of tanzania grass seeds. Eng. Agric., v.6, p.1157-1166, 2016. https://doi.org/10.1590/1809-4430eng.agric.v36n6p1157-1166/2016

MERTZ, L.M.; HENNING, F.A.; MAIA, M.S.; MENEGHELLO, G.E.; HENRIQUES, A.; MADAIL, R. Qualidade fisiológica e sanitária de sementes de feijão-miúdo beneficiadas em mesa gravitacional. Revista Brasileira de Sementes, v.29, p.1-7, 2009. 
https://doi.org/10.1590/S0101-

$\underline{31222007000300001}$

NERY, M.C.; CARVALHO, M.L.M.; OLIVEIRA, J.A.; KATAOKA, V.Y. Beneficiamento de sementes de nabo forrageiro. Revista Brasileira de Sementes, v.31, p.36-42, 2009. https://doi.org/10.1590/S0101-

$\underline{31222009000400004}$

NEVES, J.M.G; OLIVEIRA, J.A.; SILVA, H.P.; REIS, R.G.E.; ZUCHI, J.; VIEIRA, A.R. Quality of soybean seeds with high mechanical damage index after processing and storage. Agriambi, v.20, p.10251030, 2016. https://doi.org/10.1590/18071929/agriambi.v20n11p1025-1030

PESKE, S.T.; VILLELA, F.A.; MENEGHELLO, G.E. Sementes: fundamentos científicos e tecnológicos. Pelotas, 2012.

TEKRONY, D.M.; EGLI, D.B. Relationship of seed vigor to crop yield: a review. Crop Science, v.31, p.816-822, 1991. https://doi.org/10.2135/cropsci1991.0011183X0 $\underline{03100030054 x}$

TERRA-LOPES, M.L.; CARVALHO, P.C.F.; ANGIONI, I.; SANTOS, D.T.; AGUINAGA, A.Q.; FLORES, J.P.C.; MORAES, A. Sistema de integração lavourapecuária: efeito do manejo da altura em pastagem de aveia preta e azevém anual sobre o rendimento da cultura da soja. Ciência Rural, v.39, p.1499-1506, 2009. https://doi.org/10.1590/S0103-

$\underline{84782009005000096}$

TOMAZ, C. A.; MARTINS, C.C.; CARVALHO, L.R.; NAKAGAWA, J. Duração do teste de germinação do capim-tanzânia. Revista Brasileira de Sementes, v.32, p.80-87, 2010. https://doi.org/10.1590/S0101-

$\underline{31222010000400009}$

TOMAZ, C. A.; MARTINS, C.C.; SANCHES, M.F.G.; VIEIRA, R.D. Time reduction for surinam Grass seed germination test. Ciência e Agrotecnologia, v.39, p.488-497, 2015. https://doi.org/10.1590/S1413$\underline{70542015000500007}$ 